\title{
Work and School Related Variables in Teacher Motivation in Gasabo District, Rwanda
}

\author{
Patrick Gatsinzi \\ University of Eastern Africa, Baraton, Kenya. E-mail: gatsinzipatrick@yahoo.com
}

Role Jesse

University of Eastern Africa, Baraton, Kenya. E-mail: drjrole@yahoo.com

Lazarus Ndiku Makewa (Corresponding author)

University of Eastern Africa, Baraton, Kenya. E-mail: ndikul@gmail.com

\begin{abstract}
Received: December 12, 2013 Accepted: January 15, 2014 Published: July 15, 2014
doi:10.5296/jet.v1i2.4747ＵRL: http://dx.doi.org/10.5296/jet.v1i2.4747
\end{abstract}

\begin{abstract}
This paper examined work and school related variables in teacher motivation in Gasabo District of Rwanda. Two hundred and sixty seven (267) primary school teachers from Gasabo district, Kigali, participated. Systematic sampling technique was applied to choose the number of needed schools from the total of 55 in the district. Hence 15 schools were chosen as a sample population in which teachers constituting these schools were investigated. The instrument contained 50 -structured items that were measured on a four point scale with a numerical score: - strongly disagree (1), tend to disagree (2), tend to agree (3), and strongly agree (4). In order to test whether the instrument measured what it was meant to measure, a pilot survey was conducted before the final data collection so as to measure the instrument's reliability. A total of 44 teachers participated in the pilot study. The results indicate that motivation of public primary school teachers in Gasabo district is due to work supervision, responsibility assignment, and how teacher effort is acknowledged and respected. The results further indicate that in teacher motivation and school facilities related variables, only aesthetic and cleanliness significantly correlated with teacher motivation. It is recommended that educators, through reflective practice, and in-service and professional development, learn more about how to structure physical classroom settings to meet their instructional goals and activities, which would, as a result, motivate both the learner and the teacher.
\end{abstract}

Keywords: motivation, supervision, responsibility, recognition, Gasabo 


\section{Introduction}

Hodgetts and Hegar (2005) maintain that, "the psychological drive that directs a person toward an objective is motivation...motivation is a set of processes that moves a person toward a goal" (p. 39). In the context of this study, motivation is discussed in relation to the work teachers render to schools and the satisfaction they obtain from it.

In order to perform well in their teaching activities, teachers need to be motivated. There could be many factors that can affect their motivation. They range from the nature of the school infrastructure to salary, recognition/professional status, achievement, advancement/further trainings, relations with others, school leadership and policies, working conditions, recruitment, deployment, and many others. These factors also are country specific that is to say; they vary from region or country to country.

Such factors characterize the schools' effectiveness in terms of performance. Sergiovanni (2009) asserts that effective schools endeavor to create professional environments, that facilitate teachers to accomplish their tasks, participate in decisions affecting their work, have reasonable autonomy to execute their duties, share purpose, receive recognition, are treated with respect and dignity by others, work together as colleagues, and are provided with ample staff- development opportunities so as to help them develop further. This will result in teacher's creativity, persistence, and commitment to work.

Teacher motivation, although has some similarities, varies from country to country depending on the level of economic development. Literature states that motivation is influenced by a variety of factors. In the United Kingdom for example, teacher motivation and satisfaction are found to be related to working with children while dissatisfaction is related to work overload, poor pay, and how teachers are recognized by the society (Spear et al., 2000). These authors conclude that for teachers to be highly motivated, they need a high level of professional autonomy, an intellectual challenge, feel they are benefiting the society, enjoy good relations with others, and spend sufficient time working with children.

In most developing countries, however, teachers' working conditions and environment are not supportive and thus lower their motivation and commitment to teach. In South Asia (India, Pakistan, Bangladesh, Nepal) teachers' responsibility in schools is very low due to the politicization of the teaching profession. This low accountability by teachers in school matters has also a disastrous effect on other aspects of job motivation, including job promotion, school management, deployment and recruitment (Bennell, 2004).

In sub-Saharan Africa, research has it that sizeable proportions of teachers have low levels of job satisfaction and are poorly motivated; children are not well taught and thus don't receive minimal acceptable education. Most schooling systems therefore, are faced with teacher motivation crisis that are related to salary, advancement, achievement, recognition, responsibility, poor school facilities, among others which have far reaching consequences (Bennell \& Akyeampong, 2007).

In Nigeria for instance, Adelabu (2005) identifies teacher motivation as based on the way teachers are deployed, working conditions, teachers' competence, teachers' status, vocational 
intent, career advancement, fringe benefits, and remunerations. Furthermore, some schools are inadequate, dilapidated, overcrowded, lack teaching materials. Such factors are prevalent elsewhere in the least developed countries. They have an impact on the teachers' performance and academic quality and need to be improved.

In Tanzania, younger-qualified teachers are generally less satisfied than their older counterparts who still take teaching as a privilege. These younger qualified teachers are heavily concentrated in urban areas. Across Africa, there is much frustration by unqualified teachers because they are limited to opportunities to acquire basic teaching qualifications through fulltime study leave, or open distance learning programs (Bennell \& Akyeampong, 2007).

In Uganda, Okuni (2003) found that the quality of Universal Primary Education was deteriorating due to pupils' overcrowding resulting from large class sizes; inadequate training, motivation, commitment and monitoring of teachers; less active and contribution by parents; less disciplinary control of students by teachers; and lack of housing for teachers, especially in rural areas.

Rwanda as one of the developing countries in the world with the main education goal of Education For All (EFA) by 2015; has an education system where students study six years of primary school, three years of lower secondary/ordinary level, three years of upper secondary/advanced level, and four years of university-6-3-3-4 (Mineduc, 2010; Elkim, 2010).

The government recognizes that through the education sector, it can address challenges of poverty eradication, expand access to education without compromising quality, and place the country on the path of sustainable growth and development as well as achieving the millennium development goals and its vision 2020. The government, therefore, recognizes that the teacher is the main instrument in bringing about the desired improvements in quality learning (Mineduc, 2007).

With EFA, public schools experience huge turn up of pupils. This has resulted into current school enrollment of $97 \%$ compared to that of $74.5 \%$ in 2002 (Elikim, 2010; US Embassy, 2010; Rwanda Gateway, 2010), as well as overcrowding in classes where the student teacher ratio is $67: 1$. The World Bank report describes this class overcrowding as the "highest" in the world (Mineduc, 2007).

The government has tried to minimize this problem by establishing the method of "study in double shifts." This implies that some pupils of the same class study in the morning session while others in the afternoon session. This has an impact on the teacher in terms of commitment and morale to teach because he/she is the same teacher who teaches both sessions. $\mathrm{He} / \mathrm{she}$ becomes worn out in the afternoon session due to work overload.

Other government incentives and strategies to improve the education sector are- setting structures through which teachers can access loans from their cooperative bank (Umwalimu -Sacco), increase of their salary, have career advancement, increase the number of teacher training colleges and improve on the existing ones so as to have quantity and quality teachers, provide enough teaching materials, have in service trainings for both teachers and school principals, as well as set up the teacher service commission that will largely be responsible for 
teachers' improved welfare ( Mineduc, 2007; Minicofin, 2010; Nyamosi, 2011).

Despite those incentives and strategies, there is still shortage of teachers to fully teach and understand each student's learning problems. Even those few teachers are not well trained in teaching profession, their living environment is not favorable because they resort to reside in cheap houses since schools have no staff quarters, the salary pay is too little to sustain their households and this prompts them to have private income sources through private tutoring, their professional status in general is poorly recognized by the society, their career advancement structures are not well supportive, the changing of curricula especially from French to English is still a challenge, teaching many subjects and many hours in different grades/classes is hectic and stressful, getting involved in the outside school activities like representations of various social organizations/groups or elections supervision although give them some degree of recognition, it further adds burden to their teaching workload.

Bennell and Ntagaramba (2008), in their study on the teacher motivation and incentives in Rwanda found that $35 \%$ of primary school teachers and $39 \%$ of secondary school teachers in public schools were increasingly de-motivated.

In terms of infrastructure, EFA has prompted the government to put much emphasis on constructing new classrooms, especially for the lower secondary (Mineduc, 2008), with no much focus on the already existing ones, which are the teachers' daily working environment.

In order to improve on the building design, the ministry of education has established quality standards for school construction and this concerns all stakeholders. These stakeholders are the ministry of education, districts, international donor agencies, faith based organizations, private contractors, engineers, designers and architects, and all who are involved in planning, monitoring, designing procuring, constructing and rehabilitating school infrastructures (Mineduc, 2008). Those standards are stipulated in four clauses:

The school must have appropriate, sufficient and secure buildings; the school must be an environment which is health, clean, secure, and learner protecting; the school must be child friendly, barrier free environment which promotes inclusive access and equal rights of every child; and, the school must have adequate and appropriate equipment that support the level of education.

Despite such efforts however, teachers' motivation is still low and varies in relation to personal, school policies and leadership, as well as the working environment. Tailor and Vlastos (1975) assert that educational architecture is a "three-dimensional textbook," implying that the learning environment is a functional art form, a place of beauty and a motivational center for learning. They further highlight that learning environments can kindle or subdue learning, aid creativity or slow mental perceptions. Besides, school buildings are visual objects that can stimulate in terms of their intrinsic design and use.

Buckley et al. (2004) found that teachers were dissatisfied with their physical working conditions and were seeking employment elsewhere in other schools with supportive 
environment. McGowen (2007) revealed that teacher turnover as well as student discipline were significantly related to the quality of the school facility. Work environment and the availability of resources impacted teachers' job satisfaction. Their decisions to remain in teaching, was also associated with the work environment (Stallings, 2008)

Countries base on their education sector to achieve their sustainable economic development. It is the education sector that has to set standards for quality education. This quality education has to be achieved through improving the working conditions and teaching environment as well as providing incentives to teachers so that they are highly motivated and committed to teach. Various studies have revealed that a de-motivated teacher doesn't provide good education performance for the school.

When an employee's motivation is low, the performance also goes low, and so this is true with teachers in Gasabo district. Ingersoll (2001) found that lack of community support, poor opportunity for professional advancement, interferences in teaching, lack of professional competence of colleagues, intrusions on teaching time, large class sizes, inadequate time to prepare, lack of faculty influence, lack of student motivation, inadequate administrative support, student discipline problems, and unsafe environment were the lead causes of teacher dissatisfaction and poor performance.

\subsection{Theories of Motivation}

Johnson (1986) states three theories of motivation that teacher motivation is pegged on.

- Expectancy theory: This theory states that someone has to work hard for a reward.

- Equity theory: If a worker is not motivated, the work value deteriorates.

- Job enrichment theory. If work is challenging, the worker becomes more productive.

While merit pay and career ladders are dealt with in the first two theories, the third one studies distinguished staffing and "reform-oriented staff development" (NAEN, 1999).

Job enrichment theory suggests an avoidance of pain and psychological growth as two basic elements that affect motivation (Silver, 1982).

Dörnyei (2001) gives four factor motivational components:

\subsubsection{Intrinsic Component}

That there is a relationship between teaching and motivation should not be debated. A teacher who does a good job in teaching should be rewarded. The satisfaction that comes with the joy of doing a job is what is called intrinsic. With the help of this definition, intrinsic reward is divided into most satisfying views of teaching as a profession, for example, the educational process itself, and the subject matter. Teacher performance is associated with the first one, while the second has to do with getting information from the teaching environment, which improves performance and behavior. Studies show that reorganizing one's strengths and limitations builds professional effectiveness where efficacy is demonstrated through students' outcomes (Kottler \& Zehn, 2000; Wheatley, 2000). 


\subsubsection{Contextual Factors}

When workers persist to what they do, their performance is measurable. This has to do with environmental and other motivational factors that underpin work experiences. Extrinsic influences to work performance do not play a major role in job satisfaction as does intrinsic. Two types of contextual influences are listed for teacher motivation; macro-contextual, which motivate teachers towards teaching and job satisfaction, and micro-contextual, which concerns itself with organizational climate of the school or institution where the teacher works.

\subsubsection{Temporal Dimension}

Contingency paths advocate taking teaching as a lifelong career. Thus motivation in itself, for example, increases the kinds of courses taught, participating in curriculum designing and development, managing workshops dealing with teacher programs and so on and so forth, are important in teacher motivation.

\subsubsection{Negative Influences}

Teaching causes burnout (Kottler \& Zehn, 2000). Teaching is known as one of the most stressful professions. Reasons that cause burnout are emotional exhaustion, depersonalization, lack of personal accomplishment and lack of intellectual challenge. Humphreys (1996) observes that burnout is the reason of personal vulnerability and occupational stress.

Hargreaves (1998) suggests some three important factors for positive emotions: emotions by teachers should be identified and controlled early before they form a negative impact, stakeholders should work together for the sake of teaching and learning improvement and teachers should not take too much time marking exams, attending meetings, else they get bored and create dislike into the teaching profession. In addition, Pelletier et al. (2002) observes three types of pressure that affect teachers' self-determined motivation: monitoring students' behavior and academic performance, following other teachers' instructional methods, and having limited freedom in determining which curriculum to pursue.

\subsection{New Theories of Teacher Motivation}

Frase (1992) offers one reason why measures relying on external rewards have been insufficient. He says that working with students brings joy and reward in accomplishing their professional ambitions. Further, other sources indicate that teaching brings satisfaction to the teacher and this is motivation which can bring the teacher back to renewing his attitude for remaining in class (Frase, 1989; Lortie, 1976; Mitchell, Ortiz, \& Mitchell, 1987).Frase reveals that there are two factors that affect teachers' ability to perform. These are, work context factors, which include the class size, discipline and availability of instructional materials, principal's supervision competence, etc. The second factor is work content factors. These factors do not necessarily improve teaching. For example, a survey conducted by the National Center for Education Statistics showed little relation to long-term satisfaction with teaching as a career (NCES 1997). Frase (1992) emphasizes that content variables contribute highly towards motivating teachers to high levels of performance. 


\subsubsection{Work Content Factors}

Work content factors are intrinsic to the work itself. They include opportunities for professional development, recognition, challenging and varied work, increased responsibility, achievement, empowerment, and authority. Some researchers argue that teachers who do not feel supported in these states are less motivated to do their best work in the classroom (NCES 1997). Further, staff recognition, parental support, teacher participation in school decision making, influence over school policy, and control in the classroom are the factors most strongly associated with teacher satisfaction. Other research concurs that most teachers need to have a sense of accomplishment in these sectors if they are to persevere and excel in the difficult work of teaching.

Frase and Sorenson (1992) identified three major areas that relate to teachers' job satisfaction. These are feedback, autonomy and collegiality. Collegiality is directly linked to effective schools (Johnson, 1986; Glatthorn \& Fox, 1996), where teachers participated in teamwork, the outcome tended to be motivating (Little, 1982).

According to VSO (2003), teacher motivation in Rwanda was found to be strongly low and was mainly affected by financial difficulties, lack of support and tools for improving professional performance, unsupportive management, and a perception of being valued by the society. Buckley et al. (2004) found the quality of the school facility as an important predictor of teacher retention and attrition. It also affected teachers' ability to teach, their morale and health.

Since there are various factors that have been shown to be affecting the teacher motivation in a general sense; there is need to identify factors, the extent to which they motivate/ de-motivate teachers, and how they are related particularly in Gasabo district primary school teachers. These are work related and facility related factors. This study therefore, endeavored to investigate what those factors were, the extent to which they motivated teachers, and how they were related to each other in Gasabo district public primary schools.

\section{Method}

\subsection{Research Design}

Correlation research design was employed in this study.

The target population for this study was 805 primary school teachers from 55 public primary schools in Gasabo district.

The targeted sample in this study was 267 teachers from 15 public primary schools in Gasabo district, Kigali city. This sample size from the population was determined using the following formula:

$$
\mathrm{n}=\mathrm{N} / 1+\mathrm{Ne}^{2}
$$

Where $\mathrm{n}=$ sample size; $\mathrm{N}=$ population size; $\mathrm{e}^{2}=$ Margin of error; $\mathrm{n}=805 / 1+805 \times 0.05^{2}$; $\mathrm{n}=267$

Systematic sampling technique was applied to choose the number of needed schools from the 
total of 55 in the district.

Hence 15 schools were chosen as a sample population in which teachers constituting these schools were investigated. This technique was used by putting all schools on the list and selecting every " $\mathrm{n}$ "th" school for inclusion in the sample. Digit 3 was determined and assigned as the $\mathrm{n}^{\text {th }}$ number until 15 schools required were reached. After establishing the schools for study in the sample; the next process was to establish which teachers to be included in the sample. Cluster sampling technique was then employed to study all teachers in each school until the required 267 was reached for investigation.

\subsection{Research Instruments}

This study used questionnaires to collect data from 44 teachers during the pilot study and 267 teachers during the final study. It collected data on motivation, school and personal factors, as well as environmental factors that motivate teachers.

\subsection{Reliability of the Research Instruments}

In order to test whether the instrument measured what it was meant to measure, (Ng'ang'a et al., 2009), a pilot survey was conducted before the final data collection so as to measure the instrument's reliability for the final data. Pilot study for the reliability test was conducted in 4 public primary schools of Kicukiro district, Kigali city. A total of 44 teachers participated in the pilot study. In order to determine the reliability of the sample items, Cronbach's Alpha coefficient of $\geq 0.60$ was set as the cut-off point to estimate the internal consistency of the items.

After computing the pilot data in SPSS, Cronbach's Alpha coefficient on motivation was 0.731 ; school and personal factors was 0.787 ; and on environmental factors was 0.730 .This significantly illustrated that there was internal consistency of the items of the instrument and allowed the researchers to use it for final data gathering.

\subsection{Data-gathering Procedures}

After testing the validity and reliability of the instrument, we collected authorization letters were obtained from the director of graduate studies, University of Eastern Africa, Baraton and the Mayor, Gasabo district. The researchers then proceeded to 15 primary schools in Gasabo district that had been systematically sampled, to distribute the research instruments to the teachers. At the schools, the researchers introduced themselves to the school authorities who granted permission to talk to the teachers and administer the questionnaires.

\subsection{Statistical Treatment of Data}

Statistical tests were performed using SPSS. Pearson's $\boldsymbol{r}$ Product-Moment Correlation was used to measure the relationship between variables. This was applied in line with the study design (correlation research design). The level of significance was set at 0.05 . In order to determine which independent variables best predicted teacher motivation, a multiple regression technique was employed. 


\section{Results}

In this study, we examined the relationship between teacher motivation and supervision, recognition, achievement, responsibility, nature of work, school leadership and policies, advancement, noise in the classroom, light in the classroom, ventilation, aesthetic, roof, and cleanliness.

In order to determine the significant level of the relationship between the variables, Pearson correlation coefficient was employed. The following correlation matrix table indicates the significance of the relationship between variables. Significance level was set at alpha level of 0.05.

In the correlation analysis (Table 1 below), teacher motivation as a dependent variable significantly correlated with the following work related variables: Supervision $(r=0.133)$, recognition $(r=0.371)$, responsibility $(r=0.216)$, nature of work $(r=0.202)$, advancement $(r=$ $0.220)$.

Table 1. Correlations between Teacher Motivation and Work-Related Variables

\begin{tabular}{llllllll}
\hline Variables & & $\begin{array}{l}\text { Super- } \\
\text { vision }\end{array}$ & $\begin{array}{l}\text { Recog- } \\
\text { nition }\end{array}$ & $\begin{array}{l}\text { Achieve- } \\
\text { ment }\end{array}$ & $\begin{array}{l}\text { Respon- } \\
\text { sibility }\end{array}$ & $\begin{array}{l}\text { Nature of } \\
\text { Work }\end{array}$ & $\begin{array}{l}\text { School } \\
\text { Leadership } \\
\text { Policies }\end{array}$ \\
\hline \multirow{2}{*}{$\begin{array}{l}\text { Teacher's } \\
\text { Motivation }\end{array}$} & $\begin{array}{l}\text { Pearson } \\
\text { Correlation }\end{array}$ & $.133^{*}$ & $.371^{* *}$ & .059 & $.216^{* *}$ & $.202^{* *}$ & .100 \\
& $\begin{array}{l}\text { Sig. (2-tailed) } \\
\mathrm{N}\end{array}$ & .031 & .000 & .342 & .000 & .001 & .106 \\
\end{tabular}

*. Correlation is significant at the 0.05 level (2-tailed).

**. Correlation is significant at the 0.01 level (2-tailed).

The results indicate that motivation of public primary school teachers in Gasabo district is due to how work is supervised, how responsibilities are assigned, how teachers' effort is acknowledged and given due respect. Workload was found by Bennell and Akyeampong (2007) to have a huge impact on teachers' motivation and morale. These authors further recommended that increasing teachers' accountability in school matters, setting attractive career structures and improving service conditions would be imperative to teachers' performance.

Besides the work- related factors, physical facility-related factors were also examined so as to establish their relationship as highlighted in table 2 below.

Table 2. Relationship between Teacher Motivation and School-Related Variables

\begin{tabular}{llcccccc}
\hline Variable & & Noise in the Classroom & Light & Ventilation & Classroom Size & Aesthetic & Roof \\
\hline \multirow{3}{*}{ Teacher's Motivation } & Pearson Correlation & .032 & .078 & .080 & -.054 & $.174^{* *}$ & -.066 \\
& Sig. (2-tailed) & .614 & .212 & .201 & .386 & .005 & .293 \\
& $\mathrm{~N}$ & 259 & 259 & 259 & 259 & 261 & 259 \\
\hline
\end{tabular}

**. Correlation is significant at the 0.01 level (2-tailed).

*. Correlation is significant at the 0.05 level (2-tailed). 
The results indicate that in teacher motivation and school facilities related variables, only aesthetic $(\mathrm{r}=0.174)$, and cleanliness $(\mathrm{r}=0.158)$ significantly correlated with teacher motivation. A well cleaned and painted classroom is therefore crucial in motivating teachers. Makewa et al (2013) found that a tidy classroom environment had an effect on students learning the English language. They further noted that, a tidy classroom environment is thus vital for learning. Brady (2004) and Sinofsky and Knirck (1981) also found color to have serious effects on student's mood and appetite. TACIR (2003) found that color had a positive correlation with educational outcomes.

Since the classroom is a place not only for teaching but also for creation of meaning as Kaplan (2010) highlighted; its atmosphere should attract teachers to construct activities which challenge and expand the students' intelligence as well as arouse their interest in learning. These findings on aesthetic also shade light on Rice's (Tanner \& Lackney, 2006) and Lowe's (Uline \& Megan, 2008) findings on the effect of color on student improvement and learning in classroom as highlighted in the literature review.

These findings therefore, add value to the Herzberg's two factor theory (the underlying theory of this study) that workers' satisfaction depends on recognition, responsibility, clean environment, work itself, supervision, and advancement.

\subsection{Predictors of Teacher Motivation}

This paper also examined the best predictors of teacher motivation. In order to determine which independent variables best predicted teacher motivation, a multiple regression technique was employed. The variables which entered the regression were: - recognition, aesthetic, and the nature of work as indicated in table 3 below.

Table 3. Regression Analysis

\begin{tabular}{cllll}
\hline \multicolumn{3}{c}{ Model Summary } & & \\
\hline Model & R & R Square & Adjusted R Square & Std. Error of the Estimate \\
\hline 1 & $.370^{\mathrm{a}}$ & .137 & .133 & .42400 \\
2 & $.399^{\mathrm{b}}$ & .159 & .153 & .41925 \\
3 & $.418^{\mathrm{c}}$ & .175 & .165 & .41626 \\
\hline
\end{tabular}

a. Predictors: (Constant), Recognition

b. Predictors: (Constant), Recognition, Aesthetic

c. Predictors: (Constant), Recognition, Aesthetic, Nature of work

The multiple correlation coefficients of the combined variables were .418 . The best predicting variables found were recognition, aesthetic, and the nature of work. They accounted for $16.5 \%$ of the variance in teacher motivation. Jago and Tanner (1999) found that 
aesthetics affected student's attention span as well as teacher's sense of time. Kowalski (2002) indicated that color schemes complimented light in improving sight conditions as well as aesthetic qualities to space.

Ingersoll (2001) found that inadequate administrative support, lack of community support, intrusions on teaching time, inadequate time to prepare, larger classroom sizes, were among factors that characterized teachers' nature of work and contributed to teacher dissatisfaction.

Recognition as a predicting factor reflects the VSO (2003) findings that teachers in Rwanda felt neglected, ignored, and even scorned by authorities and the society despite positive relations with students.

This suggests that teachers get satisfied and highly motivated when they acknowledge other people, including the school leadership, value their rendered services and commitment to teaching. Besides, a well painted class (aesthetic) is crucial in boosting teachers' motivation.

Furthermore, the nature of work should be improved, especially in relation to procedures of doing work, support to teachers to ease stress and burnout. This should be done by allocating budgets for teacher support. It will also be of great help if the time allocated for teachers' rest between the teaching intervals is increased.

\section{Conclusions}

The results indicate that motivation of public primary school teachers in Gasabo district is due to how work is supervised, how responsibilities are assigned, how teachers' effort is acknowledged and given due respect. The results further indicate that in teacher motivation and school facilities related variables, only aesthetic and cleanliness significantly correlated with teacher motivation. The best predicting variables found were recognition, aesthetic, and the nature of work. They accounted to $16.5 \%$ of the variance in teacher motivation.

Conducive classroom environments make students put effort to achieve and experience success. Teachers also benefit out of such attractive teaching environments. Since the classroom is a place not only for teaching but also for creation of meaning, school administrators should ensure that its atmosphere should attract teachers to construct activities which challenge and expand the students' intelligence as well as arouse their interest in learning. Therefore good choice of color would improve student improvement and learning.

Educators need to become more aware of the potentials and opportunities the physical setting presents to them. They must become environmentally competent. Educators, through reflective practice, and in-service and professional development, need to learn more about how to structure physical classroom settings to meet their instructional goals and activities. These and other factors could play a major role in teacher motivation.

\section{References}

Adelabu, M. A. (2005). Teacher motivation and incentives in Nigeria. Retrieved from http://dfid.gov.uk/R4D/PDF/Outputs/policystrategy

Bennell, P. (2004). Teacher motivation in sub-Saharan Africa and south Asia. Educationpapers. 
Retrieved from www.dfid.gov.uk/R4D/PDF/Outputs/policystrategy/researchingthesisues

Bennell, P., \& Akyeampong, K. (2007). Teacher motivation in sub-Saharan Africa and south Asia. Education papers. Retrieved from www.dfid.gov.uk/R4D/PDF/Outputs/policystrategy /researching

Bennell, P., \& Ntagaramba, J. (2008). Teacher motivation and incentives in Rwanda: a situational analysis and recommended priority action.

Brady, J. (2004). Color concerns: It is not just personal preference. Retrieved from http://www.correctionalnews.com

Buckley, J., Schneider, M., \& Shang, Y. (2004). The effects of school facility quality on teacher retention in urban school districts. Retrieved from www.edfacilities.org/pubs/teachers retention.html

Donyei, Z. (2001). Motivational Strategies in the Language Classroom. Cambridge: Cambridge University Press.

Elkaim, S. (2010). Rwanda a common destiny. Retrieved from http://www.Afriquemagasine. com.

Frase, Larry E. (1989). The Effects of Teaching Rewards on Recognition and Job Enrichment. Journal of Educational Research, 83(1), 53-57.

Frase, L. E. (1992). Maximizing People Power in Schools: Motivating and Managing Teachers and Staff. Newbury Park, CA: Corwin Press, Inc.

Frase, L. E., \& Larry, S. (1992). Teacher Motivation and Satisfaction: Impact on Participatory Management. NASSP Bulletin (January 1992, pp. 37-43). http://dx.doi.org/10.1177/019263 659207654007

Hargreaves, A. (1998). The Emotional Practice of Teaching. Teaching and teacher Education, 14(8), 835-854. http://dx.doi.org/10.1016/S0742-051X(98)00025-0

Hawley, D. (1985). Designing and Implementing Performance - Based Career Ladder Plans. Educational Leadership, 43(3), 57-61.

Hodgetts, R. M., \& Hegar, K. W. (2005). Modern human relations at work (9th Ed.). Mason, $\mathrm{OH}$ : Thomson South Western.

Ingersoll, R. M. (2001). Teacher turnover, teacher shortages, and the organization of schools. Retrieved from http://depts.washington.edu/ctpmail/PDFs/Turnover-Ing-01-2001.pdf

Jago, E., \& Tanner, K. (1999). Influence of the school facility on student achievement: lighting; color. Athens, Ga.: Dept. of Educational Leadership; University ofGeorgia.

Johnson, S. M. (1986). Incentives for Teachers: What Motivates, What Matter. Educational Administration Quarterly, 22(3), 54-79. http//dx.doi.org/10.1177/0013161X86022003003

Kaplan A. (2010). Editors introduction. The risk of trust.Schools: Studies in Education, 7(1). 
University of Chicago Press.

Kottler, J. and Stanley J. Zehn. (2000). On being a teacher: The Human Dimension. California: Corwin Press.

Kowalski, T. (2002). Planning and managing school facilities. Westport, CT: Greenwood.

Little, J. W. (1982). Norms of Collegiality and Experimentation: Workplace Conditions of School Success. American Educational Research Journal, 19(3), 333.

Lortie, D. (1976). School Teacher: A Sociological Study. Chicago: University of Chicago Press.

Makewa, L., Role, E., \& Tuguta, E. (2013). Students' Perceived Level of English Proficiency in Secondary Schools in Dodama, Tanzania. International Journal of Instruction, 6(2), 35-52.

McGowen, R. S. (2007). The Impact of school facilities on student achievement,attendance, behavior, completion rate, and teacher turnover rate in selectedTexas high schools. $\mathrm{Ph} . \mathrm{D}$. dissertation, Texas A \& M University, United States -Texas retrieved from Dissertation \& Theses: Full Text. (Publication No.AAT 3296470).

MINEDUC. (2007). Teacher development and management policy in Rwanda.

MINEDUC. (2008). School Management: Training manual for secondary school head teachers. Kigali: NCDC.

MINEDUC. (2010). Fee free education.

Mitchell, D. E., Ortiz, F. I., \& Mitchell, I. K. (1987). Work Orientation and Job Performance: Toward a Cultural Theory of Work Motivation. Albany, NY. State University of New York Press.

New National Center for Education Statistics. (1997). Job Satisfaction Among America's Teachers: Effects of Workplace Conditions, Background Characteristics, and Teacher Compensation. Washington, DC: Author

Ng'ag'a, S. L. (2009). Fundamentals of management research methods. Macmillan Kenya Publishers Ltd.

North American Association of Educational Negotiators. (1999). Motivating Teachers to Improve Instruction. Oregon: Author, 15(1).

Nyamosi, Z. (2011). Teacher motivation is central to academic success. Kigali: The NewTimes.

Okuni, A. (2003). Quantity-quality trade- offs after UPE: prospects and challenges of Universal access in Uganda. Retrieved from www.norrag.org/issues/article/822/

Pelletier, L. G., Séguin-Lévesque, C., \& Legault, L. (2002). Pressure from above and pressure from below as determinants of teachers' motivation and teaching behaviors. Journal of Educational Psychology, 94(1), 186. 
Rwanda Gateway. (2010). The education system of Rwanda.

Sergiovanni, T. J. (2009). The principalship: A reflective practice perspective (6th Ed.). Texas: Pearson education, Inc.

Silver, P. (1982). Synthesis of Research on Teacher Motivation. Educational Leadership, 551-554.

Sinofsky, E. R., \& Knirck, F. G. (1981). Choose the right color for your learning style. Instructional Innovator, 26, 17-19.

Spear, M. (2000). Who would be a teacher? A review of factors motivating and de-motivating prospective and practicing teachers. London: National foundation for educational research.

Stallings, D. (2008). Public school facilities and teacher job satisfaction. Ph. D. dissertation, East Carolina University, United States - North Carolina

Tanner, K. C., \& Lackney, J. A. (2006). Educational facilities planning: Leadership, Architecture, and Management. Pearson Education, Inc.

Tennessee Advisory Commission on Inter-governmental Relations. (2003). Do K-12 school facilities affect education outcomes.

Uline, C., \& Megan, T. M. (2008).The walls speak: the interplay of quality facilities, school climate, and student achievement. Journal of education administration (vol. 46). Emerald group publishing Ltd.

VSO - Rwanda. (2003). Seen but not heard: Teachers'voices in Rwanda. A policy research report on teachers' morale and motivation in Rwanda.

Wheatley, F. (2000). Positive Teacher Efficacy as an Obstacle to Educational Reform. Journal of Research and Development in Education, 34(1), 14-27.

\section{Copyright Disclaimer}

Copyright reserved by the author(s).

This article is an open-access article distributed under the terms and conditions of the Creative Commons Attribution license (http://creativecommons.org/licenses/by/3.0/). 